\title{
STUDY OF DESORPTION OF SOME INSECTICIDES FROM FOUR NATURAL ALBANIAN CLAYS
}

\author{
Erinda Prifti ${ }^{1 *}$, Nensi Isak ${ }^{1}$, Kledi Xhaxhiu ${ }^{1}$ \\ ${ }^{1 *}$ University of Tirana, Faculty of Natural Sciences, Department of Chemistry, Albania; \\ *Corresponding Author Erinda Prifti, e-mail: prifti.erinda@gmail.com;
}

Received March 2021; Accepted April 2021; Published May 2021;

DOI: https://doi.org/10.31407/ijees11.308

\begin{abstract}
Desorption of some insecticides used in agriculture from natural Albanian clays impregnated with these insecticides is evaluated in this study. There are well-known compounds in this field such as: Dimethoate, Methomyl, Metribuzin and 2-4-D which have been studied as insecticides. The study was performed using natural clays selected from the regions of Brari, Currila, Dardha and Prrenjasi, which have been used in parallel for other studies in the field of adsorption of insecticides through natural clays. In the course study the clays were impregnated with insecticides with a concentration of $1 \mathrm{mg} / \mathrm{g}$ of clay - calculated as pure insecticide, while the desorption process was investigated from 2 hours to 24 hours and in special cases up to 48 hours. It has been noticed that the insecticides desorption from clays occurred fast, within the first few hours. Most of the insecticides are transferred into the water, with the exception of 2,4-D which desorbs slowly and for 48 hours reaches a desorption rate of $27 \%$. Based on the studied desorption process of the selected insecticides from the natural clays, it is possible to impregnate clays with different insecticides with well-calculated concentrations and use these clays in agriculture to combat crop damage. In this way the quantities of released insecticides are completely controlled and do not create environmental pollution. The use of natural clays as adsorbants/desorbants presents an effective formulation in combating crop damage. Since the insecticides desorption from clays requires a certain time, their aimed activity is prolonged whilst causing less damage on the agricultural crops.
\end{abstract}

Keywords: study, desorption, insecticides, natural albanian clays, environmental pollution 